\title{
Edukacja polonistyczna w czasach populistycznej zarazy
}

\author{
Polish language education in times of populist plague
}

\begin{abstract}
The article encourages reflection on the role of Polish language education in the face of contemporary challenges. One of them is the expansion of populism (e.g. in politics, in the media, in the way of thinking about education) and the accompanying disinformation campaigns, propaganda or replacing information analysis with emotional opinions. We are also in Poland witnessing this disturbing process, which threatens the foundations of democracy. That is why teaching a critical attitude towards theses expressed in public discourse is so important. The article shows how access to reliable information can contribute to forming such an attitude. The author also suggests that the interpretation of modern children's literature may be used to expose populist lies, harmful simplifications, and manipulation of facts; it can also successfully support the development of mature civic awareness even among very young students. The point of reference in this case is the problem of attitude towards refugees.
\end{abstract}

Keywords: populism, education, children's literature, information, opinions

\section{Pochwała sceptycyzmu}

Swoje rozważania chciałbym rozpocząć od przywołania sceny filmowej, która inicjuje opowieść o wartości niezależnego, krytycznego, ale i zaangażowanego obywatelsko dziennikarstwa. Serial Newsroom, bo o niego tu chodzi, pokazuje, jak ważne dla prawidłowego funkcjonowania obszaru publicznego są wiarygodność informacji, odpowiedzialność za słowo, odwaga, a także dystans wobec tez, zwłaszcza wygłaszanych przez polityków bez względu na to, jaką partię reprezentują. Uświadamia również, jak mocno przeświadczenia tzw. opinii publicznej są nacechowane ideologicznie i jak słabo znajdują odzwierciedlenie w faktach.

Historia wymyślona przez Aarona Sorkina zaczyna się od dziennikarskiej debaty na temat tego, jaki powinien być zasięg kompetencji amerykańskiego rządu federalnego, jak mocno jego decyzje mogą ingerować w życie społeczności 
poszczególnych stanów i amerykańskiego obywatela. Dyskusja jest gorąca, pełna emocji, złośliwości, wzajemnych uszczypliwości, a wszystko to dzieje się na oczach zgromadzonej publiczności reagującej bardzo ekspresywnie, w zależności od tego, czy podziela poglądy debatujących dziennikarzy, czy też nie. Niewiele tu możliwości i czasu na rozważenie racji, jakości argumentacji, związku między opiniami i faktami.

W tej burzliwej wymianie ciosów, z wykorzystaniem populistycznych chwytów i ksenofobicznych opinii, jeden z trzech zaproszonych gości wyraźnie czuje się nieswojo; milczy, ma trudności z koncentracją, rozgląda się wokół, jakby szukał ratunku z sytuacji, w jakiej się znalazł. Do porządku przywołuje go dopiero moderator pytający, czy chce coś dodać do słów, które już padły. Jego dowcipna odpowiedź rozładowuje napięcie. Po chwili dowiadujemy się, że tym kimś jest Will McAvoy - ceniony, znany i lubiany prezenter wiadomości.

Nagle ten inteligentny, mający poczucie humoru, dystans wobec świata oraz budzący sympatię doświadczony dziennikarz zmienia ton i stylistykę swoich wypowiedzi. Co ciekawe, dzieje się tak za przyczyną młodej obserwatorki debaty. To studentka drugiego roku, Jenny, która pyta, dlaczego Ameryka jest najwspanialszym krajem na świecie. Widać jej onieśmielenie sytuacją. Pytanie zostało sformułowane niezręcznie, a mowa ciała świadczy o zdenerwowaniu studentki; budzi ona jednak sympatię publiczności i zapewne widzów oglądających tę scenę.

Dwoje z zaproszonych dziennikarzy odpowiada jej, wymieniając takie wartości, jak różnorodność, możliwości oraz wolność. McAvoy reaguje najpierw kpiąco, podając nazwę drużyny z ligi futbolu amerykańskiego (New York Jets), a potem zniecierpliwiony dodaje, że zaproszeni goście już odpowiedzieli. Po kolejnej interwencji prowadzącego dyskusję, który nie daje za wygraną, dopowiada, że Ameryka ma najlepszą konstytucję („dzieło politycznych geniuszy”), a Deklaracja niepodległości to „najlepszy amerykański tekst”. Wszyscy są jednak rozczarowani tymi niezbyt oryginalnymi komentarzami brzmiącymi jak frazesy.

W końcu jednak nie wytrzymuje i kwestionuje tezę zawartą w pytaniu studentki, czym wywołuje zdumienie wśród zgromadzonej publiczności. Następnie atakuje swoich interlokutorów, ukazując (sarkastycznie oraz ironicznie) ideologiczne założenia przyświecające ich sądom, nieprzystawalne do rzeczywistości, zarzuca im też demagogię. Wreszcie zwraca się do dziewczyny, która zadała pytanie. Stwierdza, że świadczy ono o jej niewiedzy i niedojrzałości, Stany Zjednoczone bowiem nie są najwspanialszym krajem na świecie, ponieważ nie potwierdzają tego fakty. Potem następuje zaskakująco precyzyjne wyliczenie argumentów: Stany Zjednoczone są na siódmym miejscu w rankingu czytania ze zrozumieniem, na dwudziestym siódmym w liczeniu, na dwudziestym drugim w nauce, na czterdziestym dziewiątym w długości życia, na sto siedemdziesiątym ósmym w umieralności noworodków, na trzecim w dochodzie na gospodarstwo domowe, na czwartym ,jeśli chodzi o siłę roboczą", na czwartym w ekspor- 
cie. McAvoy daje wyraz swej irytacji coraz bardziej; ironicznie podkreśla, że Stany Zjednoczone są światowym liderem, jeśli chodzi o liczbę więźniów przypadającą na jednego mieszkańca, w wydatkach na obronę i liczbę dorosłych wierzących, że istnieją anioły.

Punkt kulminacyjny jego tyrady następuje, gdy oznajmia zaskoczonej i przerażonej jego reakcją studentce, że jest ona przedstawicielką „najgorszego pokolenia w historii”, i zarzuca jej, nie stroniąc od wulgaryzmu, że nie wie, co mówi. Zdumionej, milczącej i skonsternowanej publiczności wyznaje następnie, że Stany Zjednoczone były wspaniałe, gdy uchwalały prawa, myśląc o moralnych pryncypiach, gdy walczyły z biedą (a nie z biednymi), gdy członkowie społeczności amerykańskiej poświęcali się dla innych, troszczyli się o sąsiadów, gdy nauka pozwalała wprowadzać niezwykłe nowinki technologiczne i walczyć z chorobami, na które wcześniej nie było lekarstwa, gdy inwestowano w kulturę i rozwój myśli ekonomicznej. McAvoy tę niemal mityczną przeszłość odmalowuje bardzo patetycznie; podkreśla, że były to czasy, gdy „nie identyfikowaliśmy się z politykami i nie daliśmy się zastraszyć”. I dodaje, że „Robiliśmy to, bo byliśmy poinformowani”. A na koniec stwierdza: „Pierwszy krok na drodze do rozwiązania proble$\mathrm{mu}$, to jego rozpoznanie".

Ten trwający osiem minut serialowy prolog jest nie tylko zgrabnym wprowadzeniem $w$ fabułę filmowej opowieści rozpisanej na trzy sezony, ale zawiera też intrygującą propozycję spojrzenia na rolę edukacji we współczesnym świecie, w którym afekty dominują nad rzetelną analizą informacji, łatwość wypowiadania sądów - nad pogłębioną refleksją, kontrastowe wartościowania - nad zdolnością do dostrzegania niuansów, prawo do wyrażania własnych opinii - nad umiejętnością ich weryfikowania. Nawet najlepsza prawna i kulturowa tradycja danego państwa nie chroni przed ekspansją obrazu świata uproszczonego, schematycznego, nacechowanego emocjonalnie, z wyraźnie wydzielonymi granicami między różnymi społecznymi oraz politycznymi plemionami (Markowski, 2019) rywalizującymi w obszarze publicznego dyskursu, narzucającymi swój język, opinie, światopogląd, wartości. Chcą one w ten sposób zyskać jak najliczniejsze grono zwolenników, a równocześnie zniszczyć swych antagonistów. Tak właśnie kształtowany obraz świata funkcjonuje poza szkolnymi murami ${ }^{1}$, dlatego zasadna jest wątpliwość, czy to, co dzieje się na lekcjach w ramach edukacji polonistycznej, uodparnia uczniów na zarazę populizmu oraz inne groźne choroby współczesności, przed którymi bardzo trudno się zabezpieczyć dorosłym, a co dopiero dzieciom i młodzieży.

1 Zob. T. Garton Ash, 2018. Por. J. Bartlett, 2019; M. Castells, 2013; M. Golka, 2008; B. Siemieniecki, red., 2007; A. Kaźmierska, W. Brzeziński, 2018; S. Vaidhyanathan, 2018. 


\section{Co i dlaczego należy wiedzieć, czyli antypopulistyczna propedeutyka²}

Warto zatem, podobnie jak zrobił to filmowy bohater, przybliżyć kilka niepokojących zdarzeń, określających polityczne i medialne warunki, w jakich funkcjonuje polska szkoła. Pozwolą one uzasadnić tezę, że również Polska nie jest najwspanialszym krajem na świecie, Polacy nie są najwspanialszym społeczeństwem, a polski system edukacyjny nie proponuje najwspanialszego modelu kształcenia.

W opublikowanym 21 kwietnia 2020 roku przez organizację Reporterzy bez Granic Polska rankingu wolności prasy³ Polska została umieszczona na sześćdziesiątym drugim miejscu wśród stu osiemdziesięciu ocenianych państw (w 2015 była na miejscu osiemnastym) ${ }^{4}$. W rankingu demokracji przygotowanym z kolei przez „The Economist” (Democracy Index 2019), obejmującym sto sześćdziesiąt siedem państw świata, Polska znalazła się na miejscu pięćdziesiątym siódmym ${ }^{5}$. W 2020 roku nagrodę Freedom from Expression (przyznawaną przez Index on Censorship) za obronę wolności słowa otrzymał polski portal factchekingowy OKO.press ${ }^{6}$.

${ }^{2}$ W tytule łatwo oczywiście dostrzec nawiązanie do książki Edukacja w czasach cyfrowej zara$z y$, w której aluzja do słynnej powieści Marqueza ma charakter ironiczny. Zgadzam się z przedstawioną w tej książce koncepcją przeorientowania kształcenia humanistycznego wynikającą z rozwoju mediów cyfrowych, ale w swoim artykule (bez ironii) wskazuję równie istotny problem, jakim jest współczesna ekspansja populizmu. Zob. P. Kasprzak, P. Kołodziej, Z.A. Kłakówna, A. Regiewicz, J. Waligóra, 2016.

${ }^{3}$ https://rsf.org/en/poland [data dostępu: 19.04.2020].

${ }^{4}$ https://oko.press/polska-spada-w-rankingach-wolnosci-slowa-niezalezne-media/ [data dostępu: 19.04.2020].

${ }^{5} \mathrm{~W}$ ocenie demokracji brano pod uwagę takie czynniki, jak: proces wyborczy i pluralizm, funkcjonowanie rządu, udział obywateli w procesach politycznych, kulturę polityczną, swobody obywatelskie: „Indeks Demokracji bada jej jakość w 167 państwach na podstawie 60 pytań, na które odpowiadają wybrani eksperci. Raport nie ujawnia ich nazwisk ani narodowości. Każde państwo otrzymuje wynik w skali od 1 do 10 . W zależności od miejsca w tabeli kraje przyporządkowywane są do jednej z czterech kategorii:

1) pełna demokracja (8-10 punktów),

2) wadliwa demokracja $(6-8)$,

3) system hybrydowy (4-6),

4) system autorytarny $(0-4)$.

Według Indeksu Demokracji, w 2019 roku były 22 pełne demokracje. Listę otwierają Norwegia, Islandia i Szwecja. W 2019 roku do pierwszej kategorii awansowały Chile, Francja i Portugalia, a wypadła z niej Malta. Do 54 wadliwych demokracji należą oprócz Polski m.in. Japonia, USA, Belgia, Włochy, Kolumbia, Indie, Brazylia (ocenione wyżej niż Polska) oraz (ocenione niżej) Dominikana, Mongolia, Indonezja, Serbia, Tajlandia, Meksyk i Singapur". https://www.eiu.com/pu blic/topical_report.aspx?campaignid=democracyindex2019 oraz https://oko.press/the-economistw-rankingu-demokracji-polska-po-raz-pierwszy-nidatazej-niz-wegry/ [data dostępu: 19.04.2020].

${ }^{6}$ https://oko.press/oko-press-z-nagroda-freedom-of-expression-za-obrone-wolnosci-slowa/ [data dostępu: 19.04.2020]. Pozostali laureaci to Hong Kong Free Press (portal anglojęzyczny infor- 
Nieco wcześniej, bo 25 stycznia 2019 roku, ukazało się natomiast oświadczenie Prezydium Rady Języka Polskiego przy Prezydium Polskiej Akademii Nauk w sprawie języka agresji, w którym można przeczytać m.in., że

Stan języka debaty publicznej jest obecnie postrzegany jako jedna z głównych przyczyn negatywnych zjawisk społecznych w Polsce. [...]

Prezydium Rady Języka Polskiego ostrzega, że bez poważnej refleksji ze strony mediów i środowiska politycznego stan ten będzie zmierzał do zaostrzenia konfliktu, co może spowodować dzisiaj nieprzewidywalne, tragiczne konsekwencje. Wpływ sposobu wypowiadania się na postrzeganie rzeczywistości i jej ocenę jest decydujący. Dlatego w obliczu narastającej agresji językowej wzywamy dziennikarzy, działaczy politycznych, a zwłaszcza osoby kierujące mediami i przywódców partii do wzmożonej odpowiedzialności za słowo oraz do niepromowania postaw wyrażających się brutalnym językiem. Apelujemy o ograniczenie w przestrzeni publicznej udziału osób wypowiadających się agresywnie.

Wyrażamy głębokie przekonanie, że zmiana języka dyskursu publicznego pozwoli na stworzenie większej przestrzeni do społecznego porozumienia ${ }^{7}$.

W Sprawozdaniu o stanie ochrony jezzyka polskiego za lata 2016-2017, przedstawionym przez Radę Języka Polskiego przy Prezydium PAN marszałkowi Sejmu (datowanym na 14 marca 2019 roku), znalazły się z kolei bardzo poważne zarzuty dotyczące sposobu przekazywania informacji przez nadawcę publicznego, jakim jest TVP, nie tylko kwestionujące dziennikarską obiektywność, ale również ukazujące stronniczość przekazów medialnych i bezpardonowe traktowanie opinii krytycznych wyrażanych wobec poczynań polskiego rządu i polityków koalicji rządzącej krajem ${ }^{8}$.

To tylko kilka niepokojących symptomów ukazujących, w jakich polityczno-medialnych realiach przychodzi nauczycielom ojczystego języka rozwijać kompetencje kulturowe i lingwistyczne uczniów umożliwiające urzeczywistnienie jednego z podstawowych praw człowieka, jakim jest prawo do rzetelnej, wiarygodnej i pełnej informacji.

mujący o naruszaniu praw człowieka i swobód obywatelskich przez władze chińskie), dziennikarz Marco Ruiz Silvera działający na rzecz wolności słowa i ochrony dziennikarzy w pogrążonej w politycznym chaosie Wenezueli oraz SOS Médias Burundi, niezależny portal informacyjny działający w Burundi, państwie, z którego uciekło 80\% dziennikarzy.

${ }^{7} \mathrm{http}: / /$ www.rjp.pan.pl/index.php?option=com_content\&view=article\&id=1773: oswiad czenie-prezydium-rady-jezyka-polskiego\&catid=109\&Itemid=81 [data dostępu: 22.04.2020].

${ }^{8}$ http://orka.sejm.gov.pl/Druki8ka.nsf/0/C4B224C28DB9367BC12583CB0032CA99/\%24Fi le/3324.pdf [data dostępu: 23.04.2020]. Sprawozdanie zawiera bardzo dokładną analizę językową konkretnych wyrażeń, a ukazane w nim mechanizmy mogą być kopalnią pomysłów dydaktycznych na lekcje języka polskiego poświęcone propagandzie, manipulacji, agresji językowej oraz perswazji. 
Nie ma przypadku w tym, iż Will McAvoy swoje wyliczenie ukazujące słabości amerykańskiej demokracji rozpoczął od kwestii związanych z edukacją; jego atak na studentkę wynikał w gruncie rzeczy $\mathrm{z}$ frustracji wywołanej bezmyślnością, naiwnością i brakiem krytycyzmu tej młodej osoby9. Jej zainteresowanie debatą, które można by potraktować jako godny uznania dowód zainteresowania jakością publicznego dyskursu, wcale nie okazał się okolicznością łagodzącą, usprawiedliwiającą jej jednoznacznie pozytywną ocenę własnego państwa, a tym samym reprezentowany przez nią afirmatywny model patriotyzmu. Proponuję zatem skorzystać z serialowej inspiracji i przywołać garść danych, które opisują z kolei uwarunkowania edukacyjne, jakie są udziałem polskich uczniów i nauczycieli.

Z dokumentu Monitor Kształcenia i Szkolenia $2019^{10}$ poświęconego Polsce, przygotowanego przez Komisję Europejską w sierpniu 2019 roku, wynika m.in., że „niskie zarobki czynią zawód nauczyciela mniej atrakcyjnym”"1, „studia nauczycielskie wybiera wielu absolwentów szkół średnich, którzy osiągnęli słabe wyniki w nauce”, „karierę nauczyciela planuje mniej niż 4\% najlepszych studentów"12, a dużym wyzwaniem w najbliższym czasie będzie zastąpienie nauczycieli odchodzących na emeryturę lub rezygnujących z pracy ${ }^{13}$. Z raportu można się także dowiedzieć, że Polska inwestuje sporo $\mathrm{w}$ sektor edukacji1 ${ }^{14}$, ale nie przekłada się to na wydatki w przeliczeniu na ucznia, które są dużo niższe od średniej w Unii Europejskiej ${ }^{15}$. Interesujące są także konkluzje, spośród których warto wyeksponować następującą:

W obliczu zmieniającej się sytuacji technologicznej i demograficznej nauczyciele bardziej niż kiedykolwiek potrzebują nowych umiejętności, w tym umie-

9 Potem ją jednak zatrudnia jako swoją asystentkę, doceniając jej idealizm i zaangażowanie w sprawy publiczne; Jenny staje się częścią dziennikarskiego zespołu, ucząc się gromadzenia i weryfikowania informacji dotyczących istotnych społecznie kwestii.

${ }^{10} \mathrm{https} / /$ ec.europa.eu/education/sites/education/files/document-library-docs/et-monitor-re port-2019-poland_pl.pdf [data dostępu: 20.04.2020].

11 „Roczne wynagrodzenie zasadnicze początkującego nauczyciela według standardu siły nabywczej (PPS) wynosi jednak mniej niż połowę średniej UE - 12091 EUR w porównaniu z 25246 EUR”. https://ec.europa.eu/education/sites/education/files/document-library-docs/et-monitor-re port-2019-poland_pl.pdf [data dostępu: 20.04.2020].

12 Tamże.

${ }_{13}$ „W 2017 roku około jednej trzeciej polskich nauczycieli w szkołach podstawowych i ponadpodstawowych było w wieku powyżej 50 lat. Odsetek nauczycieli w wieku poniżej 30 lat jest stosunkowo niski w szkołach podstawowych (8,2\% w porównaniu z 11,9\% w UE) i w szkołach ponadpodstawowych, gdzie spadł z 9,1\% w 2013 roku do 5,2\% w 2017 roku (średnia UE: 8,2\%)”. https:// ec.europa.eu/education/sites/education/files/document-library-docs/et-monitor-report-2019poland_pl.pdf [data dostępu: 20.04.2020].

${ }^{14}$ W 2017 było to $4,9 \%$ PKB (średnia UE to 4,6\%). Tamże.

15 „W 2016 roku roczne wydatki publiczne w przeliczeniu na ucznia w Polsce [...] były niższe od średniej UE (według standardu siły nabywczej) - wynosiły 4777,7 EUR, podczas gdy średnia UE wynosiła 6733 EUR”. Tamże. 
jętności radzenia sobie z różnorodnością kulturową i językową w klasie, wykorzystywania technologii informacyjno-komunikacyjnych w nauczaniu oraz stosowania w nauczaniu praktyk opartych na współpracy ${ }^{16}$.

Zalecenia Komisji Europejskiej są bardzo ogólne. Warto więc zwrócić również uwagę na kontekst społeczny, w jakim polska szkoła miałaby wspierać proces „radzenia sobie z różnorodnością kulturową i językową w klasie”. Unijnym urzędnikom chodzi zapewne o rozwijanie postawy empatii, dialogu, poszanowania drugiego człowieka oraz o zapobieganie praktykom dyskryminacyjnym; sugerują również, iż edukacja ma moc sprawczą, co oznacza, że za jej pośrednictwem można realnie kształtować międzyludzkie relacje. Nie jest i nie będzie to jednak zadanie łatwe, zwłaszcza jeśli weźmiemy pod uwagę badania opisujące postawy polskiego społeczeństwa na przykład wobec uchodźców czy ekonomicznych imigrantów, a także wypowiedzi prominentnych polskich polityków odpowiedzialnych przecież także za realizowaną w naszym kraju edukację powszechną. Próba urzeczywistnienia postulatów Komisji Europejskiej może nawet oznaczać konieczność skonfrontowania uczniów z przekonaniami ich dziadków, rodziców, rówieśników, a także z poglądami znacznej części polskiego społeczeństwa.

Potwierdzenie można znaleźć na przykład w komunikacie CBOS-u dotyczącym stosunku Polaków (i Czechów) do przyjmowania uchodźców ${ }^{17}$. Szczególną uwagę zwraca dynamika zmian związana ze zgodą lub z jej brakiem na taką decyzję władz państwowych. O ile bowiem w maju 2015 roku na pytanie, „czy Polska powinna przyjmować uchodźców z krajów objętych konfliktami zbrojnymi”, $72,0 \%$ ankietowanych udzieliło odpowiedzi twierdzącej, a 21,0\% negatywnej, o tyle zaledwie trzy lata później, w czerwcu 2018 roku, taką decyzję popierało $34,0 \%$ badanych (z tego tylko 5,0\% bezwarunkowo), a 60,0\% było przeciw. Okazało się również, że jeszcze większa część społeczeństwa kategorycznie sprzeciwia się temu, by Polska, w ramach współpracy wewnątrzeuropejskiej, przyjęła część uchodźców przybywających na Stary Kontynent z Bliskiego Wschodu i Afryki (72,0\%). Z edukacyjnej perspektywy i w świetle wcześniej przywołanych oczekiwań Komisji Europejskiej mocno niepokoić powinien komentarz zamieszczony w komunikacie CBOS-u informujący, że „dezaprobatę wobec przyjmowania przez Polskę uchodźców spoza Europy częściej niż pozostali wyrażają najmłodsi ankietowani (82,0\% mających od osiemnastu do dwudziestu czterech lat)"18. Okazuje się jednak, że kiedy Polacy zostali zapytani, czy Polska

16 Zob. tamże.

17 CBOS. Komunikat z badań. 2018, nr 87. Zob. https://www.cbos.pl/SPISKOM.POL/2018/ K_087_18.PDF [data dostępu: 24.04.2020]. Zastanawia, dlaczego postanowiono polskie nastroje społeczne w tej sprawie zestawić akurat z czeskimi, a nie na przykład z niemieckimi czy ze skandynawskimi.

18 Tamże. 
powinna przyjąć ukraińskich uchodźców z terenów objętych konfliktem, twierdzącej odpowiedzi udzieliło 56,0\% respondentów, a negatywnej - 35,0\% ${ }^{19}$. Proporcje te wyraźnie kontrastują z poparciem dla przyjmowania uchodźców z krajów muzułmańskich - tylko 16,0\% badanych akceptuje oraz raczej akceptuje taką sytuację, a swój sprzeciw wyraziło aż 75,0\% pytanych ${ }^{20}$.

Ta niewielka przecież próbka danych musi zastanawiać każdego, kto zajmuje się podstawami współczesnej edukacji humanistycznej i celami, jakie powinno się za jej pośrednictwem realizować. Bez wątpienia bowiem na tak gwałtowną zmianę stosunku do uchodźców korzystających z przysługującego im prawa do poszukiwania bezpieczeństwa i godnego życia poza miejscem swojego zamieszkania, zwłaszcza w obliczu realnego zagrożenia życia, gwarantowanego w dodatku prawem międzynarodowym i konwencjami, realny wpływ miała populistyczna kampania wymierzona przeciw tej grupie, odwołująca się do negatywnych stereotypów, ukierunkowana na wywoływanie strachu i poczucia zagrożenia ${ }^{21}$. Zaskakująca w tym kontekście jest radykalna postawa młodego pokolenia, korzystającego z dobrodziejstw cyfrowych technologii, zapewniających stały dostęp do informacji, oraz z możliwości swobodnego przemieszczania się właściwie po całym świecie. Niepokojące jest też dzielenie uchodźców na lepiej i gorzej postrzeganych. Kategoryzowanie to ma wymiar emocjonalny; trudno bowiem racjonalnie wyjaśnić, dlaczego uchodźcy z ogarniętej wojną Syrii są „gorszymi” uchodźcami niż ukraińscy uchodźcy na przykład z Donbasu.

Także dane o liczbie obcokrajowców przebywających w Polsce na podstawie wydanego zezwolenia na pobyt nie pozwalają zrozumieć racjonalnych podstaw społecznej niechęci, zwłaszcza wobec osób uciekających z Syrii czy z Afryki. Nie jest to na pewno wynikiem doświadczenia spotkania z tymi ludźmi. Urząd do Spraw Cudzoziemców poinformował bowiem, że 1 stycznia 2020 roku ważne dokumenty pobytowe uprawniające do przebywania na terytorium Rzeczpospolitej Polskiej posiadało czterysta dwadzieścia trzy tysiące osób: „Największe grupy stanowili obywatele: Ukrainy - 214,7 tys. osób, Białorusi - 25,6 tys., Niemiec - 21,3 tys., Rosji - 12,5 tys., Wietnamu - 12,1 tys., Indii - 9,9 tys., Włoch - 8,5 tys., Chin - 8,5 tys., Wielkiej Brytanii - 6,3 tys. oraz Hiszpanii $-5,9$ tys." 22 .

19 Zob. tamże.

20 Dane na czerwiec 2018 rok. Zob. tamże.

21 W Internecie z łatwością można odnaleźć analizy tej kampanii, wskazujące konkretne przykłady jej realizacji, dlatego rezygnuję z ich przywołania i omówienia. Warto jednak zauważyć, że polska kultura popularna coraz częściej eksponuje te niepokojące tendencje i nastroje; można się o tym przekonać, oglądając na przykład interesujący serial Wataha, w którym jednym z istotnych wątków jest sposób traktowania uchodźców zarówno przez służby państwowe, jak i przestępców, a także skrajnie prawicowe grupy młodzieżowe.

22 https://udsc.gov.pl/legalizacja-pobytu-w-2019-r-podsumowanie [data dostępu: 24.04.2020]. 
Negatywny stosunek do przyjmowania uchodźców idzie w parze z rekomendacjami udzielanymi polskim władzom przez instytucje międzynarodowe. W 2019 roku Komitet ONZ do spraw Likwidacji Dyskryminacji Rasowej (CERD) stwierdził istotne luki prawne niepozwalające na rzeczywiste zwalczanie dyskryminacji ze względu na narodowość, pochodzenie czy kolor skóry, a także osądzanie aktów przemocy czy przejawów nienawiści im towarzyszących ${ }^{23}$. Zaapelował również o przygotowanie społecznych kampanii informacyjnych oraz inwestowanie w działania edukacyjne zapobiegające tym negatywnym zjawiskom i postawom:

Komitet zwrócił też uwagę na rolę dziennikarzy, osób publicznych i mediów w kształtowaniu języka debaty publicznej. CERD podkreślił, że odpowiedzialnością mediów jest unikanie przekazów powielających stereotypy i emitowania treści, które mogą wzmagać ksenofobiczne postawy. Komitet wyraził także zaniepokojenie faktem, że większość aktów przemocy motywowanej uprzedzeniami i nienawiścią pozostaje w Polsce niezgłoszona, a te zgłoszone często nie zostają przez ograny ścigania właściwie rozpoznane ${ }^{24}$.

Niedoszacowanie w Polsce skali problemu opisanego przez CERD potwierdza rzecznik praw obywatelskich, który na podstawie badań zrealizowanych we współpracy z Biurem Instytucji Demokratycznych i Praw Człowieka Organizacji Bezpieczeństwa i Współpracy w Europie podał w 2019 roku do publicznej wiadomości, że „najczęstszym dostrzeganym powodem dyskryminacji w Polsce jest pochodzenie etniczne i narodowość - na tę przesłankę w 2018 roku wskazało aż 49,0\% badanych i wskaźnik ten w ostatnim czasie istotnie się zwiększył”. Na policję zgłoszono natomiast tylko 5,0\% tego typu czynów ${ }^{25}$. Nie pozostaje to bez wpływu na realne sytuacje społeczne. Dowodem jest informacja umieszczona $\mathrm{w}$ tym samym raporcie:

Wskutek doświadczonej agresji, fizycznej lub werbalnej, lub w obawie przed dyskryminacją członkowie narażonych społeczności zmieniają swoje nawyki życia codziennego. Dotyczy to $46 \%$ pokrzywdzonych wywodzących się z krajów Afryki Subsaharyjskiej, które w miejscach publicznych próbują ukrywać

${ }^{23}$ Zob. https://ungc.org.pl/aktualnosci/onz-o-likwidacji-dyskryminacji-rasowej-polsce/ [data dostępu: 24.04.2020].

${ }_{24}$ Tamże. Podkreślenie autorów informacji.

${ }^{25}$ Czytamy tam również, że „aż 43\% osób z Afryki Subsaharyjskiej, 18\% obywateli Ukrainy i $8 \%$ mieszkających w Polsce wyznawców islamu mogło doświadczyć przestępstwa z nienawiści w latach 2016-2017” oraz że „aż 76\% respondentów uznało zachowanie polegające na »zwyzywaniu osoby ciemnoskórej w tramwaju « za przejaw dyskryminacji, ale tylko połowa (46\%) była świadoma faktu, że zachowanie to jest zakazane przez prawo". https://www.rpo.gov.pl/pl/content/ skala-przestepstw-motywowanych-uprzedzeniami-i-nienawi\%C5\%9Bci\%C4\%85-w-Polsce-ba dania-rpo-i-odhir [data dostępu: 24.04.2020]. 
kolor skóry (nosząc koszule z długimi rękawami nawet latem) czy 59\% Ukraińców unikających rozmawiania w swoim języku²6.

Ten przegląd warto zakończyć prezentacją danych, których się nie przywołuje w populistycznej, antyuchodźczej grze o głosy wyborców. Obrazują one skalę klęski humanitarnej, która dotyka Syrię od 2011 roku. W lapidarny sposób referuje je w „Tygodniku Powszechnym” Paweł Pieniążek:

Przynajmniej 400 tys. ludzi zginęło podczas wojny (chociaż to wątpliwy rachunek, bo już dawno stracono rachubę). Według ONZ, za granicami kraju przebywa 5,6 mln zarejestrowanych uchodźców z Syrii, jest też ponad 6,6 $\mathrm{mln}$ tzw. uchodźców wewnętrznych. Wielu z nich musiało kilkukrotnie uciekać przed wojną w różnych częściach kraju. Ponad 13 mln ludzi potrzebuje jakiejś formy pomocy. A to wszystko dzieje się w kraju, który do 2011 r. liczył 22 mln mieszkańców ${ }^{27}$.

Pieniążek, 2020

Światowe agencje informacyjne na początku 2020 roku informowały, że w samej prowincji Idlib, w północno-zachodniej Syrii, w wyniku ofensywy wojsk Baszara al-Asada i sprzymierzonych z nim sił rosyjskich, ze swoich domów uciekło około dziewięćset tysięcy mieszkańców. Z raportu Global Trend opisującego m.in. sytuację uchodźców na świecie można się dowiedzieć, że liczba uchodźców z Syrii była w 2018 roku nawet wyższa niż podana przez cytowanego Pawła Pieniążka i wyniosła 6,7 miliona. Najwięcej uchodźców z Syrii, ponad 3,6 miliona, przebywa w Turcji, ponad 944 tysiące w Libanie, ponad 676 tysięcy w Jordanii, ponad 252 tysiące w Iraku. W krajach poza regionem Bliskiego Wschodu największa liczba uchodźców trafiła do Niemiec (ponad 532 tysiące), do Szwecji (prawie 110 tysięcy) i do Sudanu (ponad 93 tysiące) ${ }^{28}$. W komentarzu do tego raportu, opublikowanym na stronie Wysokiego Komisarza Narodów Zjednoczonych do spraw Uchodźców (UNHCR), znaleźć można również raczej nieznane polskiej opinii publicznej informacje nazwane ośmioma faktami o uchodźcach. Wśród nich warto zwrócić uwagę na następujące:

W 2018 roku połowę uchodźców stanowiły dzieci, z czego wiele (111 000) było samych i bez swoich rodzin.

Jest większe prawdopodobieństwo, że uchodźca będzie mieszkał w mieście lub metropolii (60\%) niż na obszarze wiejskim lub w obozie.

${ }^{26}$ Zob. tamże. Więcej zob. Badanie charakteru i skali niezgłaszanych przestępstw z nienawiści wobec członków wybranych społeczności w Polsce. Raport z badania, 2018, Warszawa. https://www. osce.org/pl/odihr/412463?download=true [data dostępu: 24.04.2020].

${ }^{27} \mathrm{https} / /$ www.tygodnikpowszechny.pl/kraj-ktoremu-odebrano-wole-162563 [data dostępu: 20.04.2020].

${ }^{28}$ Zob. https://www.unhcr.org/globaltrends2018/ [data dostępu: 24.04.2020]. 
Kraje o wysokim dochodzie przyjmują średnio 2,7 uchodźcy na 1000 mieszkańców; kraje o średnim i niskim dochodzie przyjmują średnio 5,8 uchodźcy; kraje najbiedniejsze przyjmują jedną trzecią łącznej liczby uchodźców na całym świecie.

Około 80\% uchodźców przebywa w krajach sąsiadujących z ich ojczyznami ${ }^{29}$.

Z tymi danymi warto zestawić dwie najnowsze informacje odnoszące się do Polski. Urząd do Spraw Cudzoziemców podaje, że aktualne dokumenty uprawniające do przebywania w Polsce mają dziewięćset dziewięćdziesiąt cztery osoby pochodzące $z$ Syrii $^{30}$ (stan na rok 2020), a 2 kwietnia 2020 roku Trybunał Sprawiedliwości Unii Europejskiej orzekł, że Polska, Czechy i Węgry złamały unijne prawo, odmawiając przyjęcia uchodźców w ramach solidarnej relokacji uchodźców przybywających do Włoch i Grecji ${ }^{31}$. Parafrazując McAvoya, moż-

${ }^{29}$ https://www.unhcr.org/pl/3159-na-swiecie-jest-az-70-milionow-osob-przesiedlonychwysoki-komisarz-narodow-zjednoczonych-ds-uchodzcow-apeluje-o-wieksza-solidarnosc.html [data dostępu: 24.04.2020].

${ }^{30}$ Nie należy tej liczby utożsamiać z liczbą osób posiadających status uchodźcy. Tylko pięciu osób z dziewięciuset dziewięćdziesięciu czterech dotyczy prawo pobytu w Polsce "ze względów humanitarnych «. https://migracje.gov.pl/statystyki/zakres/swiat/typ/dokumenty/widok/mapa/rok/ $2020 / ? \mathrm{x}=-0.4656 \& \mathrm{y}=0.1888 \&$ level $=2$ [data dostępu: 24.04 .2020 ]. Dla porównania warto te dane zestawić z informacją, że „w 2019 roku kraje UE [oraz Norwegia i Szwajcaria - K.K.] wydały nieco ponad 574 tys. decyzji ws. ochrony międzynarodowej - 33\% stanowiły rozstrzygnięcia pozytywne. Najczęściej ochronę międzynarodową otrzymywali obywatele Syrii (85\%), Jemenu (82\%) oraz Erytrei (81\%)". https://udsc.gov.pl/ochrona-miedzynarodowa-w-ue-podsumowanie-2019-r/ [data dostępu: 24.04.2020]. O taką ochronę aplikowało prawie siedemdziesiąt dwa tysiące osób pochodzących z Syrii. Zob. https://easo.europa.eu/news-events/asylum-applications-eu-increase-2019 [data dostępu: 24.04.2020]. Również dane dotyczące uchodźców z Ukrainy wskazują, że Polska raczej wstrzemięźliwie rozpatruje wnioski o międzynarodową ochronę. Portal factcheckingowy Konkret24, powołując się na dane Urzędu do Spraw Cudzoziemców, podaje, że „od 2014 roku do 2018 roku Polska status uchodźcy przyznała 83 Ukraińcom, dodatkowo 235 osób objęto ochroną uzupełniającą. Według stanu na koniec marca 2019, statusu uchodźcy UdSC nie przyznał żadnej osobie z Ukrainy, a dwie objęto ochroną uzupełniającą. Dodatkowo, w latach 2014-2018 w 18 przypadkach status uchodźcy przyznała Rada ds. Uchodźców, czyli organ rozpatrujący odwołania od decyzji i zażalenia na postanowienia wydane przez Szefa UdSC. W 2019 roku - czterem osobom”. https://kon kret24.tvn24.pl/polska,108/przyjmujemy-caly-czas-uchodzcow-z-ukrainy-ilu-dokladnie, 920066. html [data dostępu: 25.04.2020]. Warto poznać jeszcze inną sprawdzoną przez portal informację: „Najwięcej mieszkańców ogarniętej wojną Syrii dostało [w Polsce - K.K.] status uchodźcy w 2015 roku -203 osoby. To $68 \%$ wnioskujących wówczas o pomoc Syryjczyków. Z roku na rok ta liczba mocno spada. W pierwszej połowie 2018 roku tylko 12 osób z Syrii, na 17 starających się, otrzymało status uchodźcy". https://konkret24.tvn24.pl/polska,108/cel-polska-podsumowujemy-dane-ouchodzcach,877337.html [data dostępu: 25.04.2020].

${ }^{31}$ Chodziło o łączną liczbę stu sześćdziesięciu tysięcy uchodźców z Syrii, Iraku oraz Erytrei. Relokacja miała trwać od 2015 do 2017 roku. Polski rząd zgodził się w jej ramach przyjąć sześć tysięcy uchodźców. Po wyborach parlamentarnych poprzedzonych agresywną kampanią antyuchodźczą realizowaną przez PiS i objęciu władzy przez tę partię zobowiązanie to nie zostało dotrzymane. 
na zatem, na podstawie analizy cytowanych dokumentów, śmiało postawić tezę, że Polska na pewno nie jest najwspanialszym krajem na świecie, zwłaszcza dla ludzi potrzebujących pomocy i domagających się respektowania podstawowych praw człowieka (dotyczy to także dzieci uciekających z obszarów objętych zbrojnymi konfliktami). Nie jest też z pewnością dla nich krajem wymarzonym, gdzie chcieliby zamieszkać i pracować.

\section{Edukacyjne marzenie (z serialem Newsroom w tle)}

Serial Newsroom pokazuje obraz młodych ludzi zainteresowanych zdobywaniem, przekazywaniem i komentowaniem informacji mających znaczenie w podejmowaniu ważnych decyzji wyborczych, ale także pozwalających zrozumieć sens i skutki aktualnych zdarzeń dziejących się w przestrzeni publicznej. To właśnie najmłodsze pokolenie pracowników stacji ACN (Atlantic Cable News) pod okiem prezentera Willa McAvoya, dyrektora wiadomości Charliego Skinnera oraz wydawczyni wieczornego serwisu MacKenzie McHale rozwija swoje kompetencje, które już w momencie, gdy je poznajemy, są wysokie. Potrafią oni sprawdzać i weryfikować źródła informacji, odnaleźć ekspertów umiejących wyjaśnić widzom złożone problemy polityczne, społeczne, gospodarcze, obnażyć sprzeczność sądów i zaskakującą ewolucję poglądów polityków oraz ich doradców, zadawać bardzo konkretne i trudne pytania oraz konsekwentnie wymagać udzielenia na nie odpowiedzi. Nie tylko przygotowują program prezentujący wiadomości. Samodzielnie szukają ważnych tematów, dbając o przestrzeganie zasad etyki dziennikarskiej, są też pełnoprawnymi uczestnikami redakcyjnego kolegium decydującego o strukturze najważniejszego serwisu informacyjnego w ciągu dnia, podczas którego ważą się losy tego, co i w jakiej kolejności zostanie pokazane, a co zostanie pominięte. Tym, co zwraca uwagę, jest też mocno wyeksponowana umiejętność słuchania i uczenia się od siebie nawzajem, wymagająca czasami przyznania się do błędów, a nawet znoszenia ironicznych, kpiących komentarzy i cierpkiej krytyki. Liczba konsultacji, których udzielają sobie bohaterowie tej filmowej historii, jest niezwykła, podobnie jak charakter więzi łączących dziennikarskich mistrzów z młodymi adeptami tej sztuki, gdzie liczą się przede wszystkim specjalistyczne umiejętności, inteligencja, błyskotliwość umysłu, poczucie humoru, sceptycyzm wobec powszechnych opinii, a nie staż, zarobki czy pozycja w dziennikarskim świecie.

Warto ten wyidealizowany, ale i uwodzicielsko przekonujący, sugestywny, mądry obraz młodego pokolenia uczynić punktem odniesienia w refleksji nad koncepcją kształcenia realizowaną $\mathrm{w}$ ramach szkolnej edukacji polonistycznej ${ }^{32}$. W interesie społecznym bowiem byłoby wychowanie właśnie takich oby-

\footnotetext{
${ }^{32}$ Idealizm filmowej opowieści dobrze współgra $\mathrm{z}$ idealistycznymi sformułowaniami zawarty-
} 
wateli (co przerażać powinno każdego populistę i demagoga). Oznacza to jednak, że do podstawowego celu edukacji humanistycznej, jakim jest wprowadzanie w tradycję kulturową, narodową, historyczną, religijną, należy dodać równie ważne cele, jakimi są objaśnianie współczesnego świata oraz przygotowanie dzieci i młodzieży na aktualne wyzwania. Jednym $\mathrm{z}$ nich jest umiejętność docierania do wiarygodnych informacji, które pozwalają kształtować opinie dotyczące spraw publicznie istotnych, a także dostarczanie narzędzi uodparniających na populizm, propagandę, manipulację, agresję językową czy dezinformację. Aby to było możliwe, należy na bieżąco monitorować problemy, które są zagrożeniem demokratycznego porządku ${ }^{33}$. Dziś można by do nich zaliczyć: zastępowanie informacji emocjonalnymi opiniami powszechnie i łatwo propagowanymi, ideologiczne kampanie realizowane za pomocą mediów społecznościowych, posługiwanie się językiem jako rodzajem broni wymierzonej przeciw jednostkom i grupom, nikłą wiedzę o zjawiskach wymagających skomplikowanych, czasami międzynarodowych rozwiązań (uchodźcy, zagrożenia związane ze zmianą klimatu), manipulowanie informacjami i selektywne ich przywoływanie itp.

Tak pojmowana edukacja powinna być apolityczna $w$ takim sensie, że nie może służyć propagowaniu określonego światopoglądu wynikającego z politycznych zapatrywań na tradycję, historię czy też współczesność (bez względu na to, kto sprawuje władzę), ale powinna być polityczna w tym sensie, że przedmiotem refleksji czyni sprawy istotne $\mathrm{z}$ punktu widzenia dobra publicznego, podtrzymując żywotność demokracji, pokazując analizowane sprawy z możliwie wielu perspektyw i odwołując się do konkretnych, wiarygodnych danych ${ }^{34}$. Im więcej afektywności w polityce i dyskursie publicznym (a skala tego zjawiska ciągle rośnie, nie tylko w Polsce), tym większa rola edukacji wymierzonej przeciw tej afektywności. Odpowiednio zaprojektowane i urzeczywistnione w szkole wychowanie obywatelskie może skutecznie uczyć nieufności wobec emocjonalnego populizmu, niesprawdzonych informacji, demagogicznych pomysłów na urządzanie świata, stawiania trudnych pytań i domagania się działań wynikających

mi w podstawie programowej, opisującymi ogólne cele polonistycznej edukacji na różnych etapach kształcenia. Można by więc potraktować serial Newsroom jako opowieść o tym, jakie mogłyby być skutki urzeczywistnienia tychże celów w perspektywie dalszej niż oceny na koniec roku czy wyniki egzaminów z języka polskiego.

${ }^{33}$ Może to robić mądry nauczyciel, ale lepiej gdyby nie było to tylko działanie jednostkowe i prowadzone na własną rękę. W takie monitorowanie powinni włączyć się niezależni eksperci oraz niezależne instytucje naukowe i edukacyjne. Sensownym rozwiązaniem byłoby powołanie doradczego zespołu, niezależnego politycznie, cyklicznie wskazującego problemy związane ze współczesnością, którymi warto się zająć w edukacji szkolnej. Takie zalecenia wymagałyby nie tylko współpracy z ministerstwem, ale też obudowy metodycznej, cyklicznych szkoleń dla nauczycieli oraz współpracy z ośrodkami uniwersyteckimi.

${ }^{34}$ Jednym ze sposobów na podejmowanie takiej refleksji jest dyskusja deliberatywna, o której pisze Ash w książce Wolne słowo. Dziesięć zasad dla połączonego świata. Proponowany sposób rozumienia polityczności można odnaleźć z pracach Hannah Arendt. 
z rzetelnie przeanalizowanych faktów lub odpowiedzi, dlaczego takich działań zaniechano ${ }^{35}$. Realizowaną przez państwo przemoc symboliczną (Bourdieu, Passeron, 1990) uda się edukacyjnie osłabiać, demaskując tkwiące w niej mechanizmy, ucząc krytycznego myślenia, a w uzasadnionych przypadkach pokazując wartość obywatelskiego nieposłuszeństwa, które przyczyniło się do rozpadu niejednego systemu autorytarnego czy totalitarnego (również w Polsce).

\section{Uchodźcy w literaturze dla dzieci, czyli szczepienie antypopulistyczne}

Polska literatura dla dzieci i młodzieży może stanowić inspirujące źródło metodycznych pomysłów pozwalających na realizowanie opisanych wcześniej zadań, i to na bardzo wczesnym etapie humanistycznej edukacji. Można się o tym przekonać, analizując i interpretując opowieści o losach najmłodszych uchodźców i sytuacji skłaniających ich rodziny do podjęcia dramatycznej decyzji o opuszczeniu własnego domu i podjęcia ryzykownej wyprawy w nieznane. Takie właśnie historie przedstawiają m.in. Liliana Bardijewska (Kot Karima i obrazki, 2016), Grzegorz Gortat (Moje cudowne dzieciństwo w Aleppo, 2017) i Rafał Witek (Chłopiec z Lampedusy, 2016). Pozwalają one przyjrzeć się złożoności uchodźczego losu, sproblematyzować go oraz uczynić tematem poważnej (i nieokazjonalnej) rozmowy z najmłodszymi uczniami. Zawierają też „przeciwciała” zwalczające populistyczną zarazę; wystawiają bowiem na światło dzienne to, co w populistycznym przekazie jest starannie ukrywane.

Proponowane utwory są opowieściami o uchodźczej egzystencji widzianej z perspektywy dzieci ${ }^{36}$, ale ich problematyka wykracza poza aktualność ukazanych zdarzeń i ma wymiar antropologiczny. Dotyczy bowiem de facto stosunku do inności, obcości, odmienności. Pozwala także wniknąć w rzeczywistość dziecka, które musi uciekać wraz z bliskim ze swojego domu, miasta, kraju, ponieważ grożą im śmierć, prześladowanie i życie w nędzy. Autorzy nie stronią od przybliżania młodym czytelnikom realiów wojny i biedy doświadczanych w ojczystych stronach przez dziecięcych bohaterów. To istotna warstwa książki Grzegorza Gortata, przedstawiającej warunki, w jakich przyszło egzystować ośmioletniej Jasmine (narratorce), jej rodzeństwu (trzyletniemu Tarikowi i sześcioletniemu Nabilowi) oraz jej rodzicom (Chalimowi i Aminie). Żyją oni w zrujnowanym mieszkaniu w Aleppo, nasłuchując, czy nie nadlatują kolejne samoloty

${ }^{35}$ Trafnie zatem domaga się Michał Paweł Markowski renesansu interpretacji jako sposobu na uzgadnianie stanowiska między ideologicznymi przeciwnikami, nie tylko politycznymi. Interpretacja ta powinna być wyprowadzona $\mathrm{z}$ twardych danych, $\mathrm{z}$ analizy zdarzeń, które nie podlegają zakwestionowaniu.

${ }^{36}$ Nawet jeśli opowiadającym jest kot, jak w książce Bardijewskiej, eksplorującym przecież w ten sposób konwencję narracyjną właściwą literaturze adresowanej do dzieci. 
zrzucające bomby, są stale przygotowani na to, by chronić się przed bombardowaniami w piwnicach pełniących funkcję schronu. Przestrzeń miejska, w jakiej przyszło im żyć, składa się z kopców gruzu, szkła, połamanych mebli, żelastwa i strzaskanych kuchennych drzwi (Gortat, 2017, s. 35), a przy tym najeżona jest licznymi niebezpieczeństwami, jak na przykład miny pułapki okaleczające i zabijające dzieci ${ }^{37}$.

Dzieła te nie szczędzą dziecięcemu odbiorcy smutnej i przerażającej analizy relacji międzyludzkich ukształtowanych w wyniku niekończącego się konfliktu zbrojnego. Ojcowie nie są w stanie zapewnić bytu swoim rodzinom, czego się wstydzą zwłaszcza przed swoimi dziećmi, matki robią wszystko, by ukryć, że nie mają czego włożyć do garnka; rodzice nie są również w stanie ochronić najmłodszych przed obrazami śmierci, cierpienia, zniszczeń. Gortat w swojej opowieści pokazuje również fanatyków religijnych niewahających się wymuszać posłuszeństwa groźbami, szantażami i przemocą, wymierzonymi przeciw niepokornym dorosłym (jak pan Safik) i dzieciom. To właśnie oni oferują Chalimowi i Aminie, rodzicom Jasmine, bezpieczne mieszkanie w innej dzielnicy — jak się okazuje, mieszkanie „bez lokatorów”, którzy zniknęli w niewyjaśnionych okolicznościach i o których los nikt nie ma odwagi zapytać (Gortat, 2017, s. 27).

W tym świecie panują zasady, na które warto zwrócić uwagę, gdyż ich zrozumienie pozwala lepiej pojąć motywacje skłaniające ludzi do ucieczki. Okazuje się na przykład, że międzynarodowa pomoc humanitarna trafia w ręce „kombinatorów i złodziei”, a transporty są często po prostu bombardowane (Gortat 2017, s. 68 i 115). Bombowce niszczą budynki szpitalne. Nie sposób pojąć dynamicznie zmieniających się układów sojuszniczych, co sprawia, że trudno odróżnić sojusznika od bandyty ${ }^{38}$ (Gortat, 2017, s. 70). Snajperzy, którymi okazują się również nastolatkowie, zmuszeni do udziału w wojnie, strzelają do cywilów (Gortat, 2017, s. 114).

${ }^{37}$ Zob. postać trzynastoletniego Haszima, kaleki organizującego piłkarską drużynę, czy Tarika, który ginie w wybuchu miny pułapki. Podobny opis syryjskiej rzeczywistości zawarty jest w książce Kot Karima i obrazki, zwłaszcza we fragmentach, w których kot Biss przedstawia historię związaną z kolejnymi obrazami narysowanymi przez Karima. Możemy tam przeczytać o wyjących w Damaszku syrenach, o bombardowaniach, o moździerzowym ostrzeliwaniu cywilów, o głodzie, o zniszczonych domach, o panicznej i nagłej ucieczce całych rodzin.

${ }^{38}$ Potwierdzenie tego, że celem militarnych ataków w Syrii są szpitale, znaleźć można w znakomitym filmie dokumentalnym Ferrasa Fayyada z 2019 roku pt. Jaskinia (The Cave), nominowanym do wielu prestiżowych filmowych nagród. Ważnymi jego bohaterami są syryjskie dzieci, często osierocone, poranione fizycznie i psychicznie. Warto ten film w ramach szkolnej edukacji humanistycznej obejrzeć i uczynić tematem refleksji na lekcjach języka polskiego. Zob. też wywiad z Amani Ballour, szefową szpitala, czyli z tytułową „Jaskinią”, która we wspominanym filmie jest jedną z najważniejszych postaci. Zob. Syryjska lekarka dla „Wyborczej”: takiego bestialstwa nikt się nie spodziewat. Wywiad przeprowadziła Marta Urzędowska. „Gazeta Wyborcza” z 1 maja 2020. https://wyborcza. pl/7,75399,25912032,syryjska-lekarka-dla-wyborczej-takiego-bestialstwa-nikt-sie.html [data dostępu: 1.05 .2020$]$. 
Dziecięcym bohaterom rozpada się ich świat; doświadczają głębokiego kryzysu w relacjach rodzinnych ${ }^{39}$ i mają coraz mniej nadziei, że coś może się zmienić $^{40}$. Szybko natomiast przyswajają reguły, które pozwalają im przetrwać w tych strasznych warunkach - wiedzą na przykład, że nie należy się bawić w pobliżu rozwieszonego prania, gdyż kolorowe rzeczy łatwo wypatrzyć z dachu, a stąd już tylko krok, by zostać łatwą ofiarą snajpera (Gortat, 2017, s. 43). Śmierć sąsiadów, znajomych czy nawet członków rodziny, mimo że sprawia ból, traktują jako jeden z oczywistych i niezmiennych elementów codziennego doświadczenia.

Liliana Bardijewska w swojej książce pokazuje, że dramat dzieci i ich rodziców wcale nie kończy się z chwilą podjęcia decyzji o ucieczce do Europy. Opowiedziana przez tę autorkę historia rozpoczyna się tam, gdzie kończy się historia Jasmine i jej rodziny. Karim ze swoją mamą i babcią w popłochu opuszczają Damaszek wraz z kolumną uchodźców, zabierając tylko podstawowe rzeczy, pieniądze, łańcuszek i kota (wbrew zaleceniom ojca, który pozostaje na miejscu ${ }^{41}$ ). Komentarze Bissa (czyli tytułowego kota) do obrazków Karima, mimo wykorzystania narracyjnej konwencji właściwej bajkom i baśniom, wcale nie ukrywają uchodźczej gehenny; raczej ją przybliżają, i to w sześciu budzących grozę odcinkach $^{42}$. Upał, pragnienie, kurz, bardzo chłodne noce, przeprawy przez rzeki, góry i urwiska, wiatr, zawieje, zamiecie, pożar to nie elementy składające się na przygodową konwencję, lecz warunki towarzyszące uchodźcom. Przeprawa przez morze okazuje się nie tyle ekscytującym wydarzeniem i próbą charakteru jak w opowiadaniu Hemingwaya o zmaganiach Santiago, ile walką imigrantów stłoczonych na małej łodzi o życie. Spotkanie z Europą i przekraczanie kolejnych granic to nieustanne stykanie się z drutami, transportami autokarowymi $\mathrm{w}$ nieznane, nocowanie $\mathrm{w}$ hangarach i namiotach, przedmiotowe traktowanie. Regularnie pojawiają się także wzmianki o konieczności opłacania przemytników, stale domagających się opłat za możliwość pokonania nadzorowanego przez nich szlaku. To również strach przed śmiercią, deportacją, kradzieżami w obozach dla uchodźców, a także poczucie poniżenia (wywołane choćby naruszeniem prawa do prywatności i intymności $)^{43}$.

39 „Tata siedział jak kukła i, patrząc w blat stołu, winił się za wszystkie nieszczęścia świata. Powtarzał dziesiąty raz z rzędu, że już dawno powinien pójść za głosem rozsądku i wyprowadzić rodzinę z miasta, tymczasem nie zrobił nic, żeby nas ocalić, kompletnie zawiódł jako głowa rodziny" (Gortat, 2017, s. 117).

${ }^{40}$ Zob. rozdział Niebo nad Aleppo kończący książkę Grzegorza Gortata.

${ }^{41}$ Warto zauważyć, że ojcowie w opowieściach Gortata i Bardijewskiej są inteligentami. Tata Karima jest lekarzem, a tata Jasmine - pracownikiem naukowym na uniwersytecie.

${ }_{42}$ Tylko siódmy obrazek Karima zawiera optymistyczne przesłanie i świadczy o przynajmniej częściowym pokonaniu traumy wywołanej ucieczką z Syrii do Europy.

${ }^{43}$ Ta literacka rzeczywistość znajduje potwierdzenie w literaturze niefikcjonalnej poświęconej uchodźcom. Zob. P. Bartolo, L. Tilotta, 2017; W. Bauer, 2016; A. Björk, M. Beijmo, 2017; S. Liberti, 2013. 
Rafał Witek również akcentuje dramat ludzi próbujących przedostać się przez Morze Śródziemne do Europy. Tandżin, około dziesięcioletni chłopiec z Erytrei, jest jednym z uchodźców ocalonych u wybrzeży Lampedusy. Jako pierwsza zauważa go Andżelika, jego rówieśniczka, która wraz z matką przebywa na Lampedusie. Dostrzegła walczącego w morzu o życie, a potem wyrzuconego przez fale na brzeg ciemnoskórego, poranionego, kuśtykającego i głodnego chłopca. Jego historia jest tylko nieco innym wariantem historii rodziny Jasmine i rodziny Karima:

Nasz dom był z gliny - ciągnął Tandżin. - Wszyscy pomagali w budowie. Cała wioska. Ale przyszli żołnierze i musieliśmy uciekać. Mama i tata sprzedali zwierzęta, przedmioty. Szliśmy przez pustynię. Potem przemytnicy powiedzieli, że mają łódź. Zapłaciliśmy, aby zawieźli nas w bezpieczne miejsce. Za morze. Tutaj. No, a resztę już wiesz...

Witek, 2016, s. 53

Przywołane teksty mają jeszcze inne edukacyjne walory. Uświadamiają, jak bardzo potrzebna jest zmiana języka, jakim opowiada się o inności. Takich lekcji udziela polskim zwierzętom syryjski kot Biss, mówiąc „Nie jestem obcy! Jestem nowy!” (Bardijewska, 2016, s. 6) oraz „Nie jestem żadnym przybłędą. Jestem uchodźcą!" (Bardijewska, 2016, s. 18). Takich lekcji udzielają też jego nowi przyjaciele, którzy z empatią wysłuchują opowieści o dramatycznym losie rodziny Karima, jak choćby mucha Klucha stwierdzająca: „Byłoby nudno, gdyby wszyscy byli stąd!" (Bardijewska, 2016, s. 13).

Utwory te dostarczają także licznych egzemplifikacji językowej dyskryminacji i wykluczenia. $Z$ takim typem przemocy spotyka się Biss przy pierwszym kontakcie z przedstawicielami polskiej fauny. Bocian Patryk informuje go: „Tu mają wstęp tylko bociany i żaby” oraz „Tutaj trzeba być tutejszym!” (Bardijewska, 2016, s. 29), ruda kotka Psotka krzyczy: „Abisyński kot z Syrii, do tego niebieski! Zabieraj się stąd! To mój kominek!” (Bardijewska, 2016, s. 17), a osa Hossa, ponieważ Biss jest niebieski, kwestionuje nawet jego istnienie: „Omam! Ciebie nie ma, słyszysz?!” (Bardijewska, 2016, s. 48). Syntezę tych wszystkich uprzedzeń prezentują groźne rottweilery, które osaczyły kota w hangarze: „Rottweilery już od dawna ostrzyły sobie na niego zęby. Dlaczego? Bo kot, bo niebieski, bo cudzoziemiec, bo przybłęda. I co ważniejsze - bo nie rottweiler!"’4 (Bardijewska, 2016, s. 64).

Antypopulistyczny wymiar analizowanych tekstów polega nie tylko na wyeksponowaniu realiów, o których populiści milczą i o których opinia publicz-

${ }^{44}$ Język wykluczenia i stygmatyzacji jest też oczywiście w przywołanych tekstach przymiotem ludzi - polski sąsiad mieszkający nad rodziną Karima nie pozwala córce bawić się z chłopcem, nazywając go „przybłędą”, a włoscy karabinierzy postrzegają Tandżina przede wszystkim przez pryzmat tego, iż jest nielegalnym imigrantem, i wdrażają odpowiednią procedurę prawną. 
na woli nie wiedzieć, czy na przedstawieniu językowego mechanizmu dyskryminowania i uprzedmiotowienia odmienności, ale również na pokazaniu korzyści wynikających ze zrozumienia sytuacji, w jakiej znaleźli się opisywani uchodźcy. Ten wychowawczy i dydaktyczny aspekt jest nie do przecenienia, ukazuje bowiem, że wiedza wyprowadzona $\mathrm{z}$ rzetelnych informacji $\mathrm{w}$ zestawieniu $\mathrm{z}$ empatią oraz gotowością wysłuchania kogoś, kto jest spoza naszej wspólnoty, grupy, społeczności, pozwala pozbyć się radykalizmu i dostrzec miałkość wcześniej formułowanych opinii. Jest to oczywiście przekonanie dziecięco naiwne, wywołujące zapewne uśmiech politowania na twarzy populistów, ale nie warto lekceważyć możliwości edukacyjnych w nim zawartych.

Bardijewska pokazuje, jak zwierzęta, do których zwykle nie ludzie nie pałają sympatią (mysz, mucha, groźne psy, sroka) lub które niczym szczególnym się nie wyróżniają (kot, chomik, bocian), najszybciej radzą sobie z akceptacją kulturowej odmienności syryjskich uchodźców i towarzyszącego im niebieskiego kota. Ale przemiana obejmuje też ludzi; polski sąsiad Karima, wprawdzie będąc w potrzebie i szukając ratunku dla rodzącej żony, zmienia jednak swój język i nastawienie, dziękując rodzinie Karima za pomoc w ich ojczystym języku. Tandżin znajduje z kolei pomoc i wsparcie nie tylko polskich imigrantek (początkowo bardzo nieufnych i uprzedzonych do erytrejskiego przybysza), ale też włoskiej emerytowanej nauczycielki, włoskiego adwokata i włoskich rodzin, którzy pomagają mu przejść wszystkie wymagane prawem procedury ${ }^{45}$.

Bardijewska, Gortat i Witek rozprawiają się także z populistycznym mitem chętnie wykorzystywanym w dyskursie publicznym, który polega na pokazywaniu uchodźców jako ludzi czekających na to, by korzystać z cudzej pracy, cudzych przywilejów socjalnych, cudzych osiągnięć technologicznych, gospodarczych, edukacyjnych (i innych), wykorzenionych ze swojej tożsamości i lekką ręką rezygnujących z własnych domów, majątków, relacji z rodziną itd. Warto pokazać zatem, że Karim z mamą uczą się języka polskiego, jego mama uczy w przedszkolu języka angielskiego, jego tata jest lekarzem leczącym polskich pacjentów. Tej syryjskiej rodzinie ciągle towarzyszy świadomość, iż należne im prawa w nowym kraju są kruche, dlatego nader często starają się o pozyskanie akceptacji (o czym świadczy nagromadzenie w tekście spójnika „bo”). Tęsknią jednak równocześnie za ojczystymi stronami. Tęskni też Tandżin, który pokazując Andżelice swój rysunek, mówi: „To mój kraj. To rodzina. Wioska. Dom. Targ. Zwierzęta. Wąż. Piach. Słońce. Rodzice. Zabawki z drutu i puszek. Ciotki Sesuna i Zewdi. A to żołnierze. Droga. Morze. Palmy. Noc. Niebezpieczeństwo" (Witek, 2016, s. 60).

45 Odnajdują się też jego rodzice, a Tandżin umawia się na spotkanie z polską przyjaciółką Andżeliką. Warto też w tym kontekście zwrócić uwagę, iż w zakończeniu swojej opowieści Gortat pozbawia czytelnika złudzeń dotyczących tego, co się stanie z rodziną Jasmine i jej podobnymi, jeśli nikt im nie pomoże i nie będą mogli znaleźć dla siebie bezpiecznego miejsca. 
W najsmutniejszej z przywołanych historii, czyli w książce Gortata, bohaterowie z kolei tęsknią za przedwojenną normalnością, codziennością bez grozy, za prawem do życia w bezpiecznym własnym kraju i bezpiecznym własnym domu. Znacząco brzmią słowa Jasmine, która wraz z rodzicami oraz bratem, na przekór nieludzkim okolicznościom, wychodzi na spacer i wygłasza słowa będące pochwałą wolności, nad wyraz dojrzałe jak na jej wiek:

Nikt nie miał ochoty wracać. Mogliśmy tak iść przed siebie kolejne trzy kwadranse albo trzy dni i trzy noce bez przerwy. Nikt nie mógł nam nic zakazać ani nie mógł do niczego zmusić. Nie uważaliśmy siebie za bohaterów, co to, to nie. Ani tym bardziej za straceńców. Po prostu chcieliśmy być wolni. Wolni i niewidzialni jak wiatr. W razie niebezpieczeństwa schowamy się w pierwszej lepszej szczelinie, gdzie nikt nas nie wypatrzy. A jeśli zdarzy się najgorsze? Wtedy po prostu rozpłyniemy się w powietrzu.

Gortat, 2017, s. 121-122

Edukacja humanistyczna, jeśli ma mieć realny wpływ na rzeczywistość, musi być edukacją zaangażowaną, interesującą się aktualnymi problemami równie mocno, jak tradycją czy przekazywaniem wiedzy z zakresu literatury i języka. Atrakcyjna i dobrze uzasadniona jest więc teza Ryszarda Koziołka porównującego humanistę do sygnalisty (Koziołek, 2019, s. 7-30). Ekspansja populizmu wywołuje jednak uzasadnione obawy, czy tak pojmowana rola humanistyki jest wystarczającym zabezpieczeniem przed groźnymi następstwami owej ekspansji. Może potrzeba pójść jeszcze krok dalej. W polskiej „wojnie wstydów”, którą scharakteryzował Przemysław Czapliński (Czapliński, 2016), lekcje ojczystego języka i literatury mają wszak do odegrania bardzo ważną rolę. Powinny opowiadać o współczesności w sposób jawnie przeciwstawny do populistycznego dyskursu, obnażając, czym grozi niedostatek informacji, manipulowanie nimi, zastępowanie ich opiniami. Dla afektywnej polityki kształtowanej pod dyktando niedoinformowanej opinii publicznej i zaspokajającej jej nawet najbardziej radykalne oczekiwania edukacja humanistyczna wychowująca dobrze poinformowane młode pokolenie, umiejące sprawdzać wiarygodność danych i mające ograniczone zaufanie do tez powszechnie uznawanych za właściwe, może być znaczącym, a zarazem trudnym przeciwnikiem. Trudno znaleźć lepsze uzasadnienie istnienia szkolnego nauczania, zwłaszcza we współczesnej rzeczywistości społeczno-kulturowej. Serial Newsroom opowiadający o perypetiach niepokornego zespołu dziennikarzy zmagających się z demagogią, głupotą, niedoinformowaniem zarówno polityków, jak i społeczeństwa pokazuje, że zawstydzanie populistów, zwłaszcza przez młodych ludzi i uczących ich nauczycieli, może sprawiać niezłą intelektualną frajdę, nawet jeśli jest skażone grzechem naiwności. 


\section{Literatura}

Badanie charakteru i skali niezgłaszanych przestępstw $z$ nienawiści wobec członków wybranych społeczności w Polsce. Raport z badania, 2018, Warszawa. https://www.osce. org/pl/odihr/412463?download=true [data dostępu: 24.04.2020].

Bardijewska L., 2016, Kot Karima i obrazki, Łódź 2016.

Bartlett J., 2019, Ludzie przeciw technologii. Jak Internet zabija demokrację (i jak możemy ja ocalić), Umiński K., przeł., Katowice.

Bartolo P., Tilotta L., 2017, Lekarz z Lampedusy. Opowieść o cierpieniu i nadziei, Stopa K., przeł., Kielce.

Bauer W., 2016, Przez morze. Z Syryjczykami do Europy, Kalinowska E., przeł., Wołowiec.

Björk A., Beijmo M., 2017, Łódź 310. Śmierć na Morzu Śródziemnym, Kowadło-Przedmojska I., przeł., Warszawa.

Bourdieu P., Passeron J.C., 1990, Reprodukcja. Elementy teorii systemu nauczania, Neyman E., przeł., Warszawa.

Castells M., 2013, Władza komunikacji, Jedliński J., Tomanek P., przeł., Warszawa.

Czapliński P., 2016, Wojna wstydów, „Teksty Drugie”, nr 4, s. 17-45.

Garton Ash T., 2018, Wolne słowo. Dziesięć zasad dla połązonego świata, Godyń M., Godyń F., przeł., Kraków.

Golka M., 2008, Bariery w komunikowaniu i społeczeństwo (dez)informacyjne, Warszawa.

Gortat G., 2017, Moje cudowne dzieciństwo w Aleppo, Warszawa.

http://orka.sejm.gov.pl/Druki8ka.nsf/0/C4B224C28DB9367BC12583CB0032CA99/ \%24File/3324.pdf [data dostępu: 23.04.2020].

http://www.rjp.pan.pl/index.php?option=com_content $\&$ view=article\&id=1773: oswiadczenie-prezydium-rady-jezyka-polskiego\&catid=109\&Itemid=81 [data dostępu: 22.04.2020].

https://easo.europa.eu/news-events/asylum-applications-eu-increase-2019 [data dostępu: 24.04.2020].

https:/ec.europa.eu/education/sites/education/files/document-library-docs/et-monitorreport-2019-poland_pl.pdf [data dostępu: 20.04.2020].

https://konkret24.tvn24.pl/polska,108/cel-polska-podsumowujemy-dane-o-uchodz cach,877337.html [data dostępu: 25.04.2020].

https://migracje.gov.pl/statystyki/zakres/swiat/typ/dokumenty/widok/mapa/rok/ $2020 / ? \mathrm{x}=-0.4656 \& \mathrm{y}=0.1888 \&$ level $=2$ [data dostępu: 24.04 .2020 ].

https://oko.press/oko-press-z-nagroda-freedom-of-expression-za-obrone-wolnoscislowa/ [data dostępu: 19.04.2020].

https://oko.press/polska-spada-w-rankingach-wolnosci-slowa-niezalezne-media/ [data dostępu: 19.04.2020].

https://oko.press/the-economist-w-rankingu-demokracji-polska-po-raz-pierwszynidatazej-niz-wegry/ [data dostępu: 19.04.2020].

https://rsf.org/en/poland [data dostępu: 19.04.2020].

https://udsc.gov.pl/legalizacja-pobytu-w-2019-r-podsumowanie [data dostępu: 24.04.2020]. 
https://udsc.gov.pl/ochrona-miedzynarodowa-w-ue-podsumowanie-2019-r/ [data dostępu: 24.04.2020].

https://easo.europa.eu/news-events/asylum-applications-eu-increase-2019 [data dostępu: 24.04.2020].

https://konkret24.tvn24.pl/polska,108/przyjmujemy-caly-czas-uchodzcow-z-ukrainyilu-dokladnie,920066.html [data dostępu: 25.04.2020].

https://ungc.org.pl/aktualnosci/onz-o-likwidacji-dyskryminacji-rasowej-polsce/ [data dostępu: 24.04.2020].

https://www.cbos.pl/SPISKOM.POL/2018/K_087_18.PDF [data dostępu: 24.04.2020]. https://www.eiu.com/public/topical_report.aspx?campaignid=democracyindex 2019 [data dostępu: 19.04.2020].

https://www.rpo.gov.pl/pl/content/skala-przestepstw-motywowanych-uprzedzeniami-inienawi\%C5\%9Bci\%C4\%85-w-Polsce-badania-rpo-i-odhir [data dostępu: 24.04.2020].

https://www.unhcr.org/globaltrends2018/ [data dostępu: 24.04.2020].

https:/www.unhcr.org/pl/3159-na-swiecie-jest-az-70-milionow-osob-przesiedlonychwysoki-komisarz-narodow-zjednoczonych-ds-uchodzcow-apeluje-o-wieksza-soli darnosc.html [data dostępu: 24.04.2020].

https://wyborcza.pl/7,75399,25912032,syryjska-lekarka-dla-wyborczej-takiego-bestial stwa-nikt-sie.html [data dostępu: 1.05.2020].

Kasprzak P., Kołodziej P., Kłakówna Z.A, Regiewicz A., Waligóra J., 2016, Edukacja w czasach cyfrowej zarazy, Torun.

Kaźmierska A., Brzeziński W., 2018, Strefy cyberwojny, Warszawa.

Koziołek R., 2019, Humanista sygnalista, w: tegoż, Wiele tytułów, Wołowiec.

Liberti S., 2013, Na południe od Lampedusy. Podróże rozpaczy, Wyrembelski W., przeł., Wołowiec.

Markowski M.P., 2007, Wojny nowoczesnych plemion. Spór o rzeczywistość w epoce populizmu, Kraków.

Pieniążek P., Kraj, któremu odebrano wole, „Tygodnik Powszechny” z 14 marca 2020 roku. https://www.tygodnikpowszechny.pl/kraj-ktoremu-odebrano-wole-162563 [data dostępu: 20.04.2020].

Siemieniecki B., red., 2007, Manipulacja - media - edukacja, Toruń.

Vaidhyanathan S., 2018, Antisocial Media. Jak Facebook oddala nas od siebie i zagraża demokracji, Mincer W., przeł., Warszawa.

Witek R., 2016, Chłopiec z Lampedusy, Łódź.

Krzysztof Koc - profesor Uniwersytetu im. Adama Mickiewicza w Poznaniu, doktor habilitowany w zakresie literaturoznawstwa, kierownik Pracowni Innowacji Dydaktycznych UAM w Poznaniu, sekretarz naukowego czasopisma metodycznego „Polonistyka. Innowacje”. Jego zainteresowania badawcze koncentrują się wokół reportażu oraz szkolnej edukacji humanistycznej podejmującej dialog ze współczesnością. Opublikował dwie książki: Czytanie świata. Reportaże Ryszarda Kapuścińskiego w edukacji polonistycznej (Poznań 2007) i Lekcje myślenia (obywatelskiego). Edukacja polonistyczna wobec współczesnego świata (Poznań 2018). Jest również współautorem podręczni- 
ka akademickiego dydaktyki kształcenia polonistycznego Innowacje i metody. W kręgu teorii i praktyki (Poznań 2011).

e-mail: kocyk@amu.edu.pl 